NBER WORKING PAPER SERIES

\title{
FOREIGN ENTRY INTO U.S. MANUFACTURING BY TAKEOVERS AND THE CREATION OF NEW FIRMS
}

\author{
Zadia Feliciano \\ Robert E. Lipsey \\ Working Paper 9122 \\ http://www.nber.org/papers/w9122 \\ NATIONAL BUREAU OF ECONOMIC RESEARCH \\ 1050 Massachusetts Avenue \\ Cambridge, MA 02138 \\ September 2002
}

This study is being performed under grant number SES-9911390 from the National Science Foundation. The statistical analysis of firm-level data reported in this study was conducted at the International Investment Division, U.S. Bureau of Economic Analysis, under arrangements that maintained legal confidentiality requirements. The views expressed are those of the authors and do not necessarily reflect those of the Bureau of Economic Analysis or the National Science Foundation. Special thanks are due to Li $\mathrm{Xu}$ and Jessica Rosen for excellent research assistant work and to the BEA for allowing us to use their facilities. We are indebted to Maria Borga, of the Bureau of Economic Analysis, for valuable comments on an earlier version of this paper presented at the annual conference of the Western Economic Association, and to participants at a session of the International Trade and Finance Association and a seminar at the Graduate Center of CUNY. The views expressed herein are those of the authors and not necessarily those of the National Bureau of Economic Research.

(C) 2002 by Zadia Feliciano and Robert E. Lipsey. All rights reserved. Short sections of text, not to exceed two paragraphs, may be quoted without explicit permission provided that full credit, including @ $\odot$ notice, is given to the source. 
Foreign Entry into U.S. Manufacturing by Takeovers and the Creation of New Firms

Zadia Feliciano and Robert E. Lipsey

NBER Working Paper No. 9122

September 2002

JEL No. F21, F23, G34

\begin{abstract}
Using U.S. Bureau of Economic Analysis data for individual foreign acquisitions and new establishments in the U.S from 1988 to 1998, and aggregate data for 1980 to 1998, we find that acquisitions and establishments of new firms tend to occur in periods of high U.S. growth and take place mainly in industries in which the investing country has some comparative advantage in exporting. New establishments are largely in industries of U.S. comparative disadvantage, and the relation of U.S. comparative advantage to takeovers is also negative, but never significant. High U.S. stock prices, industry profitability, and industry growth discourage takeovers. High U.S interest rates and high investing country growth and currency values encourage takeovers.

Direct investments in acquisitions and new establishments thus tend to flow in the same direction as trade. They originate in countries with comparative advantages in particular industries and flow to industries of U.S. comparative disadvantage.
\end{abstract}

Robert E. Lipsey

NBER

365 Fifth Avenue, 5th Floor

New York, NY 10016

rlipsey@gc.cuny.edu

\section{Zadia Feliciano}

NBER

365 Fifth Avenue, 5th Floor

New York, NY 10016

and Queens College

Flushing, NY 11367

zadia_feliciano@qc.edu 
The United States became a magnet for international direct investment flows in the late 1980s, reversing its former, and traditional, position as mainly a supplier of direct investment to other countries. After some decline in the early 1990s, the inflows again expanded rapidly, reaching a twenty-year peak in 2000 before a sharp decline, by almost half, in 2001, especially in the second half of the year. Most of the direct investment inflow has been in the form of acquisitions of U.S. firms by foreign owners. Over the last twenty years, foreign firms have spent over $\$ 1$ trillion on these acquisitions and acquired more than $\$ 2$ trillion in U.S. firm assets. The purpose of this paper is to explain the timing and the anatomy of new foreign direct investment in the United States. Using U.S. Bureau of Economic Analysis data for individual firms from 1988 to 1998 we construct panels of foreign acquisitions and new establishments by industry and country of ultimate beneficial owner (UBO). We use this panel to examine the question of what determines changes in the percent of total U.S. assets taken over or in newly established foreign firms, what determines the industries in which takeovers and new establishments occur, and what influences the country sources of these investments.

We examine the macro economic conditions of countries making the investments, the industries into which the investments have flowed, the relation between the countries making investments in the U.S. and the industries targeted, and the differences between determinants of takeovers and of the establishment new enterprises. The analysis by country and industry, not feasible without the use of confidential individual firm data at the Bureau of Economic Analysis, expands the current literature and provides us with a better understanding of why and when these investments take place.

Outlays for additions to the universe of foreign- owned firms in the United States consist of those for new establishments and those for acquisitions of existing firms. An establishment 
takes place if "...the foreign parent or its existing U.S. affiliate creates a new legal entity that is organized and begins operating as a new U.S. business enterprise or directly purchases U.S. real estate." An acquisition takes place if "...the foreign parent or its existing U.S, affiliate obtains a voting equity interest of 10 per cent or more in an existing U.S. business enterprise and continues to operate it as a separate legal entity or purchases a business segment or operating unit of an existing U.S. business and organizes it as a new separate legal entity. A U.S. business is also categorized as 'acquired' if an existing U.S. affiliate purchases a U.S. business, a segment of a U.S. business, or an operating unit of a U.S. business and merges it into its own operations.” (Howenstine and Troia, 2000, pp. 58-59). The foreign acquisitions have far exceeded the new establishments. Our data show that, between 1988 and 1998, outlays for acquisitions accounted for $83 \%$ of outlays for acquisitions and new establishments.

Figure 1 shows the increase in the absolute value of assets in acquisitions and in new foreign establishments in the United States between 1980 and 1998. Figure 2 shows that there were no trends in the ratio of assets of acquired and newly established foreign firms to total corporate assets in the United States.

Much of the literature on foreign takeovers and other investment inflows has concentrated on the impact of exchange rate movements and, to a smaller extent, stock price movements, on their size and timing. The relation to exchange rates has sometimes been taken to represent a price effect, with declines in a currency value thought to lower the price of a country's assets and therefore encourage their purchase by foreigners. Froot and Stein (1991) argued, in explaining the capital inflows of the 1970s and 1980s, that since buyers from all countries would have access to the same international capital markets, a price decline brought about by currency depreciation would be the same for buyers regardless of their location, and 
would not favor foreign buyers. They suggested instead that the effect of currency value changes was a wealth effect, making holders of the depreciating currency poorer and holders of the appreciating currency richer, and that it was through this wealth effect that a depreciation of the currency favored foreign bidders for business assets. They also suggested that this theory is supported by evidence on the effects of stock price movements, such as those in Japan between 1987 and 1991.

Klein and Rosengren (1990) further tested the wealth hypothesis by regressing FDI outlays from 1971 to 1991 on the real exchange rate, relative labor costs and relative stock market values. The evidence strongly supports the wealth hypothesis over the relative labor cost hypothesis. ${ }^{1}$ Using transaction- specific data on foreign acquisitions of U.S. targets from 1975 to 1989, Dewenter (1995) found that when the relative stock market value is included as an explanatory variable, FDI flows are not significantly affected by exchange rates.

The literature on the characteristics of firms acquired by foreign investors is more limited. Using a sample of firms acquired by foreign and domestic firms in 1988, Chen (1997) finds that foreign acquisitions are more common in industries with low average annual growth rates in value added, higher capital-labor ratios, lower market concentration ratios and lower import tariff rates. Gonzalez and Vasconcellos (1998) studied foreign acquisitions during the 1981-1990 period using a control sample of companies and found that U.S. companies with lower returns on equity and lower sales growth are more likely to be taken over by foreign firms. They view these findings as evidence of inefficient management of the domestic companies targeted by foreign firms.

\footnotetext{
${ }^{1}$ The relative-labor-cost theory argues that relative labor costs across major industrial countries have been largely determined by currency movements during the floating exchange rate period. The wealth theory argues that the wealth of firms relative to their foreign counterparts rises with a currency appreciation.
} 
In this paper we use panel data on assets acquired through foreign direct investment, by industry and country of origin (UBO), from the Bureau of Economic Analysis BE-13 survey of new and acquired foreign establishments in the U.S. ${ }^{2}$ By federal law, all foreign entities acquiring or establishing U.S. firms must notify the U.S. government and complete the survey. Thus, the response rate is close to $100 \%$. These data for individual firms are not publicly available since they are confidential and confidentiality problems have limited the publication even of detailed country and industry data. For this reason, they have not been previously used to analyze foreign direct investments in the U.S.

For this study, data were aggregated to 50 industries and twelve of the more important investing countries. These data were then merged with the U.S. Internal Revenue Survey Statistics of Income for Corporations, representing complete coverage of U.S. corporations.

We can think of each country as having a population of entrepreneurs more skilled in managing some industries than others. A rise in country A's currency value will increase the wealth of its entrepreneurs and raise their demand for firms in country B, especially in industries where they can improve productivity or profitability. A rise in prices of equities in country A would have similar effects. Within the host country, the sale of assets in its less efficient industries would free capital to move to the country's more efficient sectors.

An economic development that would affect acquisitions, but not necessarily new establishments, would be a worldwide decline in the cost of cross-border mergers and acquisitions. If we imagine two countries with managerial skills in different industry sectors, a decline in acquisition costs or a liberalization of acquisition rules would mean that country A's firms would tend to acquire country B firms in the sectors where country A firms are superior.

\footnotetext{
${ }^{2}$ The title of the survey is Internal Report on a Foreign Person's Direct or Indirect Acquisitions, establishment or purchase of the operating assets, of a U.S. Business Enterprise, Including Real Estate. It is both mandatory and
} 
Country B's firms would acquire country A firms in the sectors of country B's superiority. Both countries would gain in efficiency as their entrepreneurs' capital moved to sectors in which they were most skilled and out of industries in which they were least skilled. Such liberalization of cross-border mergers might account for trends in merger activity if we find them.

While investment outlays might reflect the market for control of assets, they do not reflect the size of the impact on host countries, since a given outlay could purchase control of various amounts of assets, depending on how leveraged the target firms were or became. To study host-country impacts, we use the measure of assets of acquired and established firms. To allow for the possibility that capital markets are segmented by country, interest rates in home and host countries can be included in the equations.

Equation 1 uses the publicly available data for aggregate takeover activity, which cover the period 1980 to 1990 (U.S. Department of Commerce, BEA, 1999a, 1999b, 1999c and 2000), with some of the variables suggested by earlier literature, to explain the share of total assets acquired.

$$
\begin{aligned}
& \frac{A A_{t}}{T A_{t}}=\alpha+\beta_{1} \operatorname{Pr} o f U S_{t}+\beta_{2} \operatorname{Pr} o f A_{t-1}+\beta_{3} \text { Stock }_{t}+\beta_{4} \text { ROWStock }_{t}+\beta_{5} \text { REx }_{t}+\beta_{6} \text { Int }_{t}+ \\
& \beta_{7} G D P G r_{t}+\varepsilon_{t} \text { (1) }
\end{aligned}
$$

$A A_{t}$ is total assets acquired in year $\mathrm{t}$ by foreign entities. $T A_{t}$ is total U.S. corporate assets. $\operatorname{ProfUS}_{t}$ is the average profitability of US corporations (net income after taxes/assets). Prof $\mathrm{A}_{\mathrm{t}-1}$ is the average profitability of acquired firms during the year prior to takeover. Stock $k_{t}$ is the price of U.S. stocks measured by the Standards and Poors 500. ROWStock $k_{t}$ is a weighted average of stock prices of the top 12 countries making foreign direct investments in the U.S. ${ }^{3} R E x_{t}$ is the real

confidential information.

3 A fixed weight was used based on the proportion of investments made by each country in 1980 . 
effective exchange rate in year $\mathrm{t}$ (value of the dollar). Int $t_{t}$ is the short-term interest rate in the United States. GDPGr, is the GDP real growth rate.

Several versions of this equation are shown in Table 1. The best of these equations includes both the average profitability of all U.S. corporations and the average profitability of the acquired firms in the year before takeover. The only variables significant at the 5 percent level are the real effective exchange rate and the interest rate. The real effective exchange rate (value of the dollar) has the expected negative sign. A higher price for the dollar discourages takeovers, as earlier aggregate studies have found. U.S. interest rates have an unexpected positive coefficient, suggesting the effect of a tight U.S. credit market on U.S. target firms. The coefficient for U.S. Profitability has a negative sign but it is not significant.

Table 2 represents an equation similar to equation 1, for new establishments. The variable for the previous year's profitability is omitted, since a new firm has no previous year. The coefficient for U.S. profitability negative, but not significant, as for takeovers. The U.S. stock price index is a significantly negative influence when U.S. average profitability is not included. The coefficient for ROW Stock Price is positive and significant. This result is consistent with the wealth effect literature. The interest rate coefficient is positive, as it is for takeovers. The exchange rate, important for takeovers, is negative, but not significant for new establishments. Thus the main differences between the explanations for takeovers and for new establishments are, for the latter, the negative and significant coefficient for the U.S. stock price index and the positive and significant coefficient for ROW stock price index.

The variables included in equation 1 can be thought of as reflecting the macroeconomic situation in the US and investing countries. The results suggest that there are macroeconomic influences on flows of direct investment, although what Froot and Stein (1991, p. 1192) refer to 
as "the modern theory of FDI," perhaps more appropriately the ancient theory of FDI, stresses microeconomic influences. These are the firm-specific advantages that enable a firm to operate in an alien environment despite the advantages of local knowledge and experience that host country firms presumably possess. In their words, "A German auto manufacturer...may be able to manage an existing plant more efficiently than his U.S. counterpart, and would be willing to pay a price that exceeds the American's valuation" (ibid). Our interest is mainly in the country sources and industry destinations of the investment flows. That is, who is taking over existing U.S. firms or establishing new ones? In which industries are U.S. firms being acquired by foreigners or are new foreign firms being established? And what is the relationship between the country sources of the investment inflow and the industries to which it is going?

There are two more or less competing explanations for the sources and directions of the direct investment inflow. One is that foreign firms wish to gain access to U.S. locational advantages, based on U.S. factor endowments or U.S. technological skills that are specific to the country rather than to U.S. firms. In that case, we would expect to find that investment would be attracted to industries in which the United States had some comparative advantage in trade.

The second explanation is that foreign firms have built up firm-specific advantages in their own countries, based on their home countries' current or past comparative advantages, and wish to exploit these in the United States, where firms have lost, or never acquired, these skills. In that case, we would expect to find that investment would flow to industries of U.S. comparative disadvantage, and would come from firms in industries in which their own home countries had comparative advantages in trade. That this type of flow might be a characteristic of direct, in contrast to portfolio, investment was suggested many years ago by John Dunning (1970, p. 4). 
To examine this question, we assume that investing companies' firm-specific advantages are associated with their countries' comparative advantages in trade. We identify these with the "revealed" export comparative advantage of the United States and each investing country. That is measured by the share of an industry in a country's exports relative to its share in world exports.

If the first explanation is correct, we would expect that U.S. comparative advantage in an industry would be positively associated with investment inflows, and a foreign country's comparative advantage in an industry would be associated with low levels of investment in the United States. If the second explanation were correct, we would expect that a comparative advantage for the United States in an industry would discourage foreign firms from entering. And we would expect that a comparative advantage in industry $i$ of country $j$ relative to the United States would have a positive effect on country j's acquisitions and establishments of U.S. firms in industry $i$.

We first look for the influence of U.S. comparative advantage in equation 2 by examining inflows by industry, for 50 manufacturing industries, not disaggregating by country of origin.

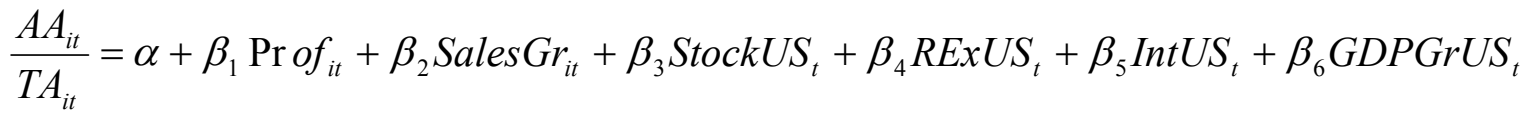

$$
\begin{aligned}
& +\beta_{7} \operatorname{USCompAdv}_{i t}+\operatorname{Ind}_{i}+\varepsilon_{t}
\end{aligned}
$$

$A A_{i t}$ is the acquired assets by foreign entities in industry $\mathrm{i}$ and year $\mathrm{t}, T A_{i t}$ is the total U.S. corporate assets in industry i and year t, $\operatorname{Prof}_{i t}$ is the average profitability of US corporations (net income after taxes/assets) in industry i and year t, Sales $G r_{i t}$ is the average growth rate of sales in industry i and year t, StockUS $S_{t}$ is the price of stocks in the U.S. in year $\mathrm{t}$ (Standards and Poors $500), \operatorname{Rx} U S_{t}$ is the real effective exchange rate in year $\mathrm{t}$ (value of the dollar), $\operatorname{Int} U S_{t}$ is the short 
term interest rate in the U.S. in year $\mathrm{t}, G D P G r U S_{t}$, is the GDP real growth rate in year $\mathrm{t}$ and USCompAdv $v_{i t}$ is the U.S. comparative advantage in year $\mathrm{t}$ and $I n d_{i}$ represents 49 industry dummies. The results for several versions of this equation are shown in Table 3 for foreign acquisitions and in Table 4 for newly established foreign firms.

In Table 3, of the macroeconomic variables, the U.S. Stock price, the U.S. interest rate, and U.S. GDP growth rate appear to be significant influences on the rate of acquisition within industries. High U.S. stock prices are associated with lower levels of acquisitions. Higher U.S. GDP growth rates are associated with increases in the share of assets acquired. The U.S. interest rate is positively related to acquisitions. Of the industry variables, the profitability of industries is negatively related to takeovers, reinforcing the previous results that takeovers occur when overall profitability is low. U.S. industry sales growth is negatively related to acquisitions. The coefficient for U.S. comparative advantage is negative but not significant. Both industry and year dummies add to the explanation, and the equation omitting the exchange rate and U.S. interest rates, but including industry and year dummies, is the best of the four. The year dummies probably pick up the influence of some of the macroeconomic variables, but they also perform another important function. That is to allow for some of the lumpiness of major acquisitions, which produce extreme outliers, as must have been the case, for example, for the Daimler takeover of Chrysler.

There are a number of possible explanations for the industry dummy variables. They could reflect the comparative advantages of the United States, with U.S. comparative advantage deterring takeovers. Another possibility is that they might be unrelated to any country's comparative advantage but reflect worldwide movements toward consolidation of some 
industries into larger units. In that case, firms in country A are buying firms in country B at the same time as firms in country B are buying firms in country A.

The equations for new establishments are quite different from the acquisition equations (see Table 4). The US GDP growth rate has a positive and significant influence on the establishment of new foreign operations, as expected. The U.S. stock price index is not significant. U.S. comparative advantage in an industry appears as a negative influence on new establishments in equations omitting the industry dummies. The industry dummies reflect U.S. comparative advantage plus other industry characteristics.

Since different potential investing countries would be expected to possess different comparative advantages, we further disaggregate inflows by country, for the 12 largest U.S. investors. The countries are Australia, Belgium, Canada, France, Germany, Italy, Japan, Mexico, Netherlands, Sweden, Switzerland and the United Kingdom. These countries account for $85 \%$ of the value of acquisitions. The corresponding equation is equation 3 .

$$
\begin{aligned}
& \frac{A A_{i j t}}{T A_{i t}}=\alpha+\beta_{1} \operatorname{Pr} o f_{i t}+\beta_{2} \text { SalesGr }_{i t}+\beta_{3} \text { StockUS }_{t}+\beta_{4} R \operatorname{ExUS} S_{t}+\beta_{5} \operatorname{IntUS}_{t}+\beta_{6} \text { GDPGrUS }_{t} \\
& +\beta_{7} \text { USCompAdv }_{i t}+\beta_{3} \text { StockF }_{j t}+\beta_{4} \text { RExF }_{j t}+\beta_{5} \text { IntF }_{j t}+\beta_{6} \text { GDPGrF }_{j t}+\beta_{7} \text { FCompAdv }_{i j t} \\
& + \text { Ind }_{i}+\text { Cntry }_{j}+\varepsilon_{t} \text { (3) }
\end{aligned}
$$

$A A_{i j t}$ is the assets acquired by foreign entities from country $\mathrm{j}$ in industry $\mathrm{i}$ and year $\mathrm{t}, T A_{i t}$ is the

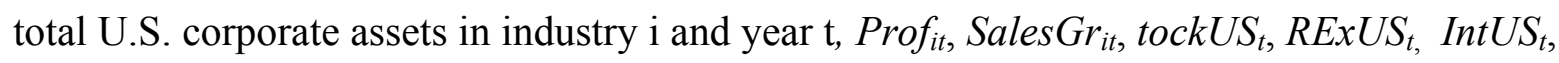
$G D P G r U S_{t}, U S C o m p A d v_{i t}$ and $I n d_{i}$ are defined as before. The additional variables StockF $F_{j t}$, $\operatorname{Rex}_{j t}, \operatorname{Int} F_{j t}, G D P G r F_{j t}$, and $F C o m p A d v_{i t}$ are defined as the stock price, the price of US $\$$ in terms of the foreign currency, the interest rate, the GDP growth and Comparative Advantage of foreign countries making the investments. A country dummy variable $C n^{\prime} y_{j}$ has been also included. The country dummy variables are introduced as a crude way to take account of the 
very different sizes of the potential investing countries, as well as of country differences in the extent of involvement in U.S. financial markets.

The results for several versions of this equation are given in Table 5 for foreign acquisitions, and in Table 6 for new establishments of foreign firms. Acquisitions tended to be higher when industry profitability and growth in net income and sales were lower than average. Growth of sales is significant in all specifications and both variables are significant at the 5 percent level in the fourth specification. Acquisitions are negatively related to the U.S. stock price, as expected, and positively related to the U.S. growth rate. As before, the US interest rate appears to be positively related to acquisitions. Foreign countries invest more when their GDP is growing faster and when the exchange values of their currencies are higher. Foreign stock prices are not significantly related to acquisitions.

Another strong influence on acquisitions is the foreign country's comparative advantage. The coefficient is significant only when industry dummies are not included, since comparative advantage measures do not vary significantly from year to year, and therefore tend to be obliterated by industry dummies. Foreign firms have been acquiring U.S. firms in industries in which their countries have a comparative advantage in exports. U.S. comparative advantage in an industry is expected to be an obstacle to foreign takeovers, but that coefficient, while negative, is never significant.

Investments in new foreign- owned firms are more difficult to predict in terms of macroeconomic conditions in the U.S. or the foreign country. The only significant macroeconomic variable shown in Table 6 is U.S. GDP growth. New investments appear to be more closely related to the comparative advantage in the foreign country and the U.S. All regressions show a significant and positive influence of foreign countries' comparative 
advantage in an industry on new investments (Table 6). In addition, they show a significant negative effect of U.S. comparative advantage when the industry dummy variables are not included. When they are included, the U.S. comparative advantage coefficient disappears, indicating that the influence of U.S. comparative advantage involves differences across industries, but not changes over time.

\section{$\underline{\text { Conclusions }}$}

To analyze takeovers and new investments we used aggregate data (19 years), industry data (11 years and 50 industries) and industry by country data (11 years, 50 industries and 12 countries). The aggregate data show that foreign acquisitions and new firm establishments both tend to occur at times of relatively low U.S. firm profitability, but high U.S. interest rates. Acquisitions are discouraged by high values of the U.S. dollar, but new establishments are not. New establishments, but not acquisitions, tend to take place in years of high U.S. stock prices.

In the industry and industry-by-country data, we find that acquisitions and establishments of new firms tend to occur in periods of high U.S. GDP growth and both take place mainly in industries in which the investing country has some comparative advantage in exporting relative to the world. New establishments are largely in industries of U.S. comparative disadvantage, and the relation of U.S. comparative advantage to takeovers is also negative, but never significant.

The other macro and industry variables seem to influence only takeovers. High U.S. stock prices, industry profitability, and industry growth discourage takeovers. High U.S. interest rates and GDP growth and high growth and high values for currencies in investing countries encourage takeovers. Thus there is some support in these data for the influence of investing country and receiving country wealth effects on takeovers. There is stronger evidence for the 
importance of industry and country specific influences. Direct investments flow in the same direction as trade, from countries with comparative advantages in particular industries to industries of U.S. comparative disadvantage, particularly when those U.S. industries are growing slowly and are relatively unprofitable. The positive influence of high U.S. interest rates may also reflect periods of financial stringency for U.S. enterprises.

Inflows of direct investment into the United States occur mainly in industries in which the United States is not an international leader. And they tend to originate in countries that are leaders in those industries. Both facts suggest that foreign takeovers of existing U.S. firms and the establishment of new foreign-owned firms tend to put U.S. establishments and U.S. assets in the hands of more skillful owners. 


\section{$\underline{\text { References }}$}

Chen, Chih-Hsiang (1997), "The determinants of Foreign and Domestic Merger Activities in U.S. Manufacturing Industries.” Ph.D. Dissertation, The University of Wisconsin.

Dewenter, Kathryn L. (1995), “Do Exchange Rate Changes Drive Foreign Direct Investment?"Journal of Business, Vol. 68, No. 3, July, pp. 405-433.

Dunning, John H. (1970), Studies in International Investment, London, George Allen \& Unwin. Federal Reserve System, Board of Governors (2000), "Flow of Funds Accounts of the United States, Flows and Outstanding, Third Quarter 2000”, December.

Feenstra, Robert C., Robert E. Lipsey, and Harry Bowen (1997), “World Trade Flows, 1970 1992, with Production and Tariff Data," Cambridge, MA, NBER Working Paper No. 5910, January.

Froot, Kenneth A., and Jeremy C. Stein (1991), "Exchange Rates and Foreign Direct Investment: An Imperfect Capital Markets Approach,” Quarterly Journal of Economics, Vol. CVI, Issue 4, November.

Gonzalez, Pedro, Geraldo M. Vasconcellos and Richard J. Kish (1998), “Cross-Border Mergers and Acquisitions: The Under valuation Hypothesis.” The Quarterly Review of Economics and Finance, Vol. 38, No. 1, Spring 1998, pp. 25-45.

Howenstine, Ned G., and Rosaria Troia (2000), "Foreign Direct Investment in the United States: New Investment in 1999,” Survey of Current Business, Vol. 80, No.6, June, pp.55-63. International Monetary Fund (2000), International Financial Statistics Yearbook 2000, CDROM, International Monetary Fund. 
Klein, Michael W. and Eric Rosengren (1994), "The real exchange rate and foreign direct investment in the United States." Journal of International Economics, Vol. 36, May, pp. 373-389.

U.S. Department of Commerce, Bureau of Economic Analysis (1999a), "Foreign Direct Investment in the United States: U.S. Business Enterprises Acquired or Established by Foreign Direct Investors, 1980-91”. (1999b), “Foreign Direct

Investment in the United States: U.S. Business Enterprises Acquired or Established by Foreign Direct Investors, 1992-97, July. (1999c), "National Income and Product Accounts Tables," Survey of Current Business, Vol. 79, No.12, pp.44-148, Table 1.16 . (2000), “Foreign Direct

Investment in the United States: U.S. Business Enterprises Acquired or Established by Foreign Direct Investors, 1998-99," June.

United States, Internal Revenue Service (1997), Statistics of Income, Corporate Income Tax $\underline{\text { Returns. }}$ United States, President (2001), Economic Report of the President, January Weinberg, Douglas B. (2000), “U.S. International Transactions, First Quarter 2000,” $\underline{\text { Survey of }}$ Current Business, Vol. 80, No. 7, July, pp.79-123. 


\section{$\underline{\text { Data Definitions and Sources }}$}

The aggregate data on takeovers are from U.S. Department of Commerce (1989, 1993, 2000a, and 2000b). These are based on the data recorded in the BEA's survey form BE-13, and the original returns from that survey are the basis for the analysis by country and industry.

U.S. and other country (UBO) growth in GDP are taken from U.S. Department of Commerce (1998, 1999, and 2000) and from the World Bank's 1999 World Development Indicators CD-ROM and the World Bank web site.

Business profitability in the aggregate for each country is Operating surplus of corporate and quasi-corporate enterprises as per cent of gross product of such enterprises, and is from OECD National Accounts, Vol. II.

Share prices, interest rates, nominal exchange rates, and the U.S. real effective exchange rate are from the IMF International Financial Statistics CD-ROM, lines reu, rf or rh, 60p, and 62. U.S. corporate assets and profits, by industry, are from the U.S. Internal Revenue Service Statistics of Income from Corporations.

Comparative advantage is calculated from the NBER World Trade Data Base (Feenstra, Bowen, and Lipsey, 1997), updated from later versions of the Statistics Canada World Trade Data Base. 


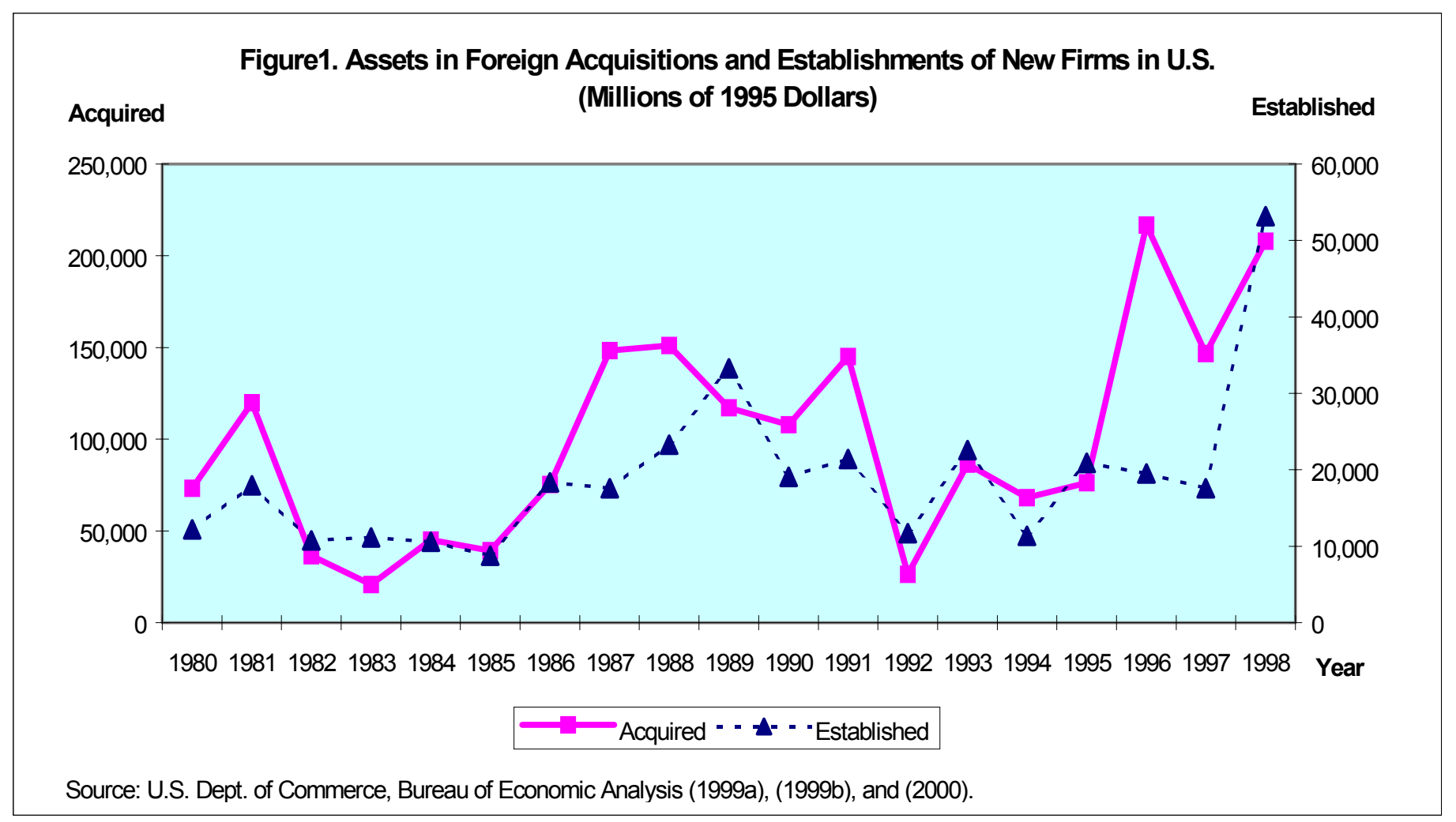

Source: U.S. Dept. of Commerce, Bureau of Economic Analysis (1999a), (1999b), and (2000).

Figure2. Assets in Foreign Acquisitions and New Establishments as Per Cent of Total U.S. Corporate Assets

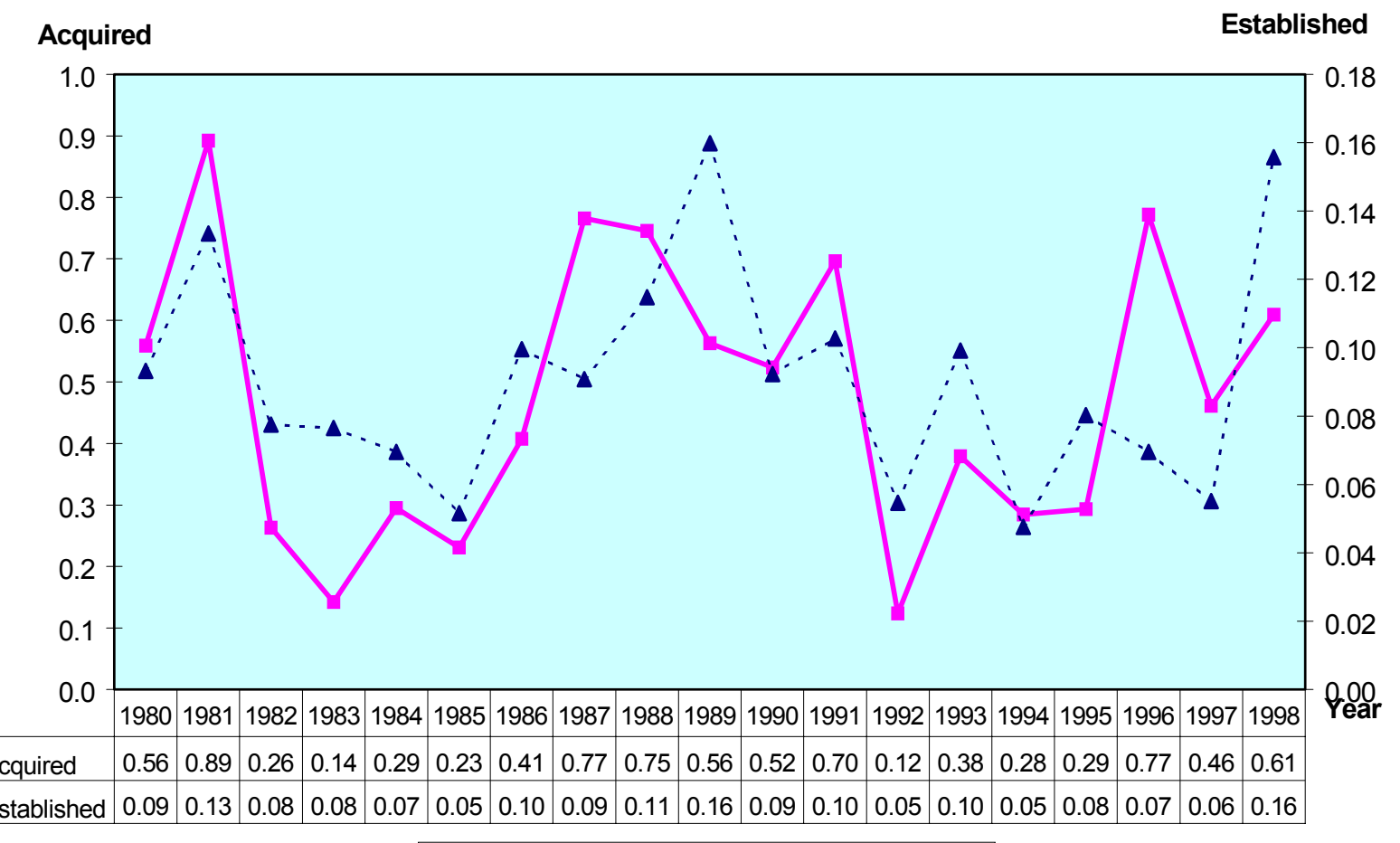

\section{$\longrightarrow$ Acquired $\cdots \star-$ Established}

Note: U.S. total assets for 1998 is extrapolated from 1997 \& 1998 total assets figures from Board of Governors of the Federal Reserve System (2000).

Sources: U.S. Internal Revenue Service (1997) and the same series in the previous issues; U.S. Dept. of Commerce, Bureau of Economic Analysis (1999a), (1999b), (1999c), and (2000); Board of Governors of the Federal Reserve System (2000). 


\begin{tabular}{|c|c|c|c|}
\hline & (1) & (2) & (3) \\
\hline US Profitability & & $\begin{array}{l}-0.045 \\
(0.057)\end{array}$ & $\begin{array}{l}-0.046 \\
(0.057)\end{array}$ \\
\hline Acquired Firm Profitability & & & $\begin{array}{c}0.031 \\
(0.034)\end{array}$ \\
\hline US Stock Price & $\begin{array}{l}-0.011 \\
(0.007)\end{array}$ & $\begin{array}{ll} & -0.007 \\
& (0.008)\end{array}$ & $\begin{array}{l}-0.007 \\
(0.008)\end{array}$ \\
\hline ROW Stock Price ${ }^{1}$ & $\begin{array}{c}0.014 \\
(0.008)\end{array}$ & $\begin{array}{c}0.011 \\
(0.008)\end{array}$ & $\begin{array}{c}0.010 \\
(0.009)\end{array}$ \\
\hline Real Effective Ex-rate x $10^{-3}$ & $\begin{array}{l}-5.710 \\
(2.740)\end{array}$ & ** $\begin{array}{ll} & -5.910 \\
& (2.800)\end{array}$ & $\begin{array}{ll}* * & -5.370 \\
& (2.880)\end{array}$ \\
\hline Interest Rate & $\begin{array}{c}0.064 \\
(0.021)\end{array}$ & $\begin{array}{c}* * 0.080 \\
(0.029)\end{array}$ & $\begin{array}{cc}* * & 0.060 \\
& (0.037)\end{array}$ \\
\hline GDP Growth Rate & $\begin{array}{c}0.005 \\
(0.027)\end{array}$ & $\begin{array}{c}0.003 \\
(0.028)\end{array}$ & $\begin{array}{l}-0.008 \\
(0.030)\end{array}$ \\
\hline $\begin{array}{l}\text { Number of Observations } \\
\text { Adjusted R-Squared }\end{array}$ & $\begin{array}{c}19 \\
0.30\end{array}$ & $\begin{array}{c}19 \\
0.28 \\
\end{array}$ & $\begin{array}{c}19 \\
0.27 \\
\end{array}$ \\
\hline
\end{tabular}

Numbers in parentheses are standard errors.

* Significant at the $10 \%$ level, ${ }^{* *}$ Significant at the $5 \%$ level

Sources: U.S. Dept. of Commerce, Bureau of Economic Analysis (1999a), (1999b), (1999c), and (2000).

International Monetary Fund (2000).

United States President (2001).

1.ROW Stock Price is a weighted average of stock prices of the top 12 countries making foreign direct investments in the U.S. A fixed weight was used based on the proportion of investments made by each country in 1980 . 


\begin{tabular}{|c|c|c|c|c|}
\hline \multicolumn{5}{|c|}{$\begin{array}{l}\text { Table 2: Determinants of New Establishments in the United } \\
\text { States Aggregate Data, 1980-1998 } \\
\text { Dependent Variable: Newly Established Assets/Total U.S. Assets } \\
\end{array}$} \\
\hline US Profitability & & & $\begin{array}{l}-0.010 \\
(0.008)\end{array}$ & \\
\hline US Stock Price & $\begin{array}{c}-.002 \\
(0.001)\end{array}$ & $* *$ & $\begin{array}{c}-.001 \\
(0.001)\end{array}$ & \\
\hline ROW Stock Price ${ }^{1}$ & $\begin{array}{c}0.003 \\
(0.001)\end{array}$ & $* *$ & $\begin{array}{c}0.002 \\
(0.001)\end{array}$ & \\
\hline Real Effective Ex-rate x $10^{-3}$ & $\begin{array}{l}-0.341 \\
(0.410)\end{array}$ & & $\begin{array}{l}-0.394 \\
(0.405)\end{array}$ & \\
\hline Interest Rate & $\begin{array}{c}0.008 \\
(0.003)\end{array}$ & $* *$ & $\begin{array}{c}0.012 \\
(0.004)\end{array}$ & $* *$ \\
\hline GDP Growth Rate & $\begin{array}{l}-.001 \\
(.004)\end{array}$ & & $\begin{array}{l}-.002 \\
(.004)\end{array}$ & \\
\hline $\begin{array}{l}\text { Number of Observations } \\
\text { Adjusted R-Squared }\end{array}$ & $\begin{array}{c}19 \\
0.21\end{array}$ & & $\begin{array}{c}19 \\
0.24\end{array}$ & \\
\hline
\end{tabular}

Numbers in parentheses are standard errors.

* Significant at the $10 \%$ level, ** Significant at the $5 \%$ level

Sources:

U.S. Dept. of Commerce, Bureau of Economic Analysis (1999a), (1999b), (1999c), and (2000).

International Monetary Fund (2000).

United States Government Printing Office (2001).

1.Row stock price is a weighted average of stock prices of the top 12 countries making foreign direct investments in the U.S. A fixed weight was used based on the proportion of investments made by each country in 1980 . 


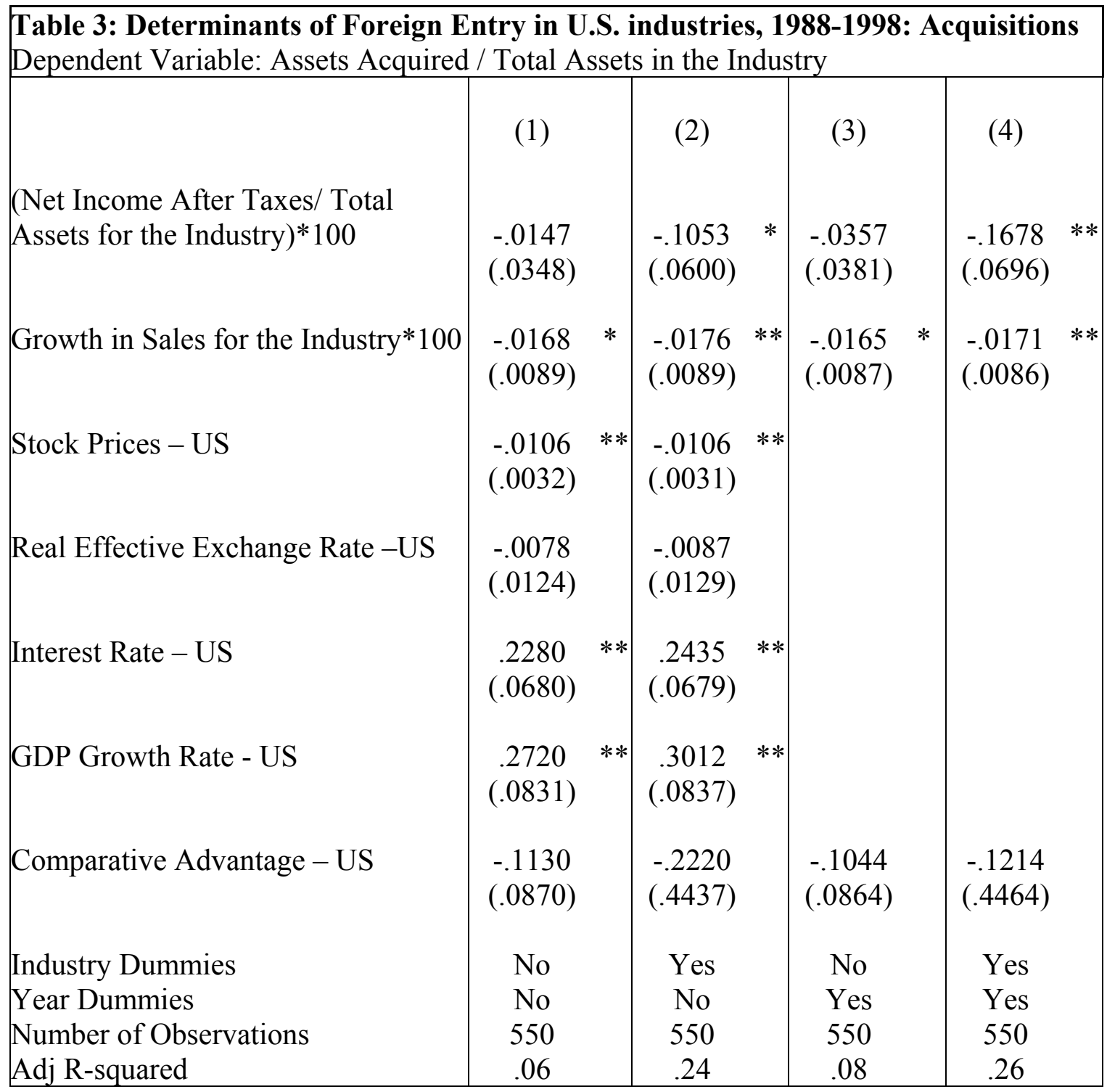

Numbers in Parentheses are Standard Errors.

* Significant at the $10 \%$ Level, ** Significant at the 5\% Level 


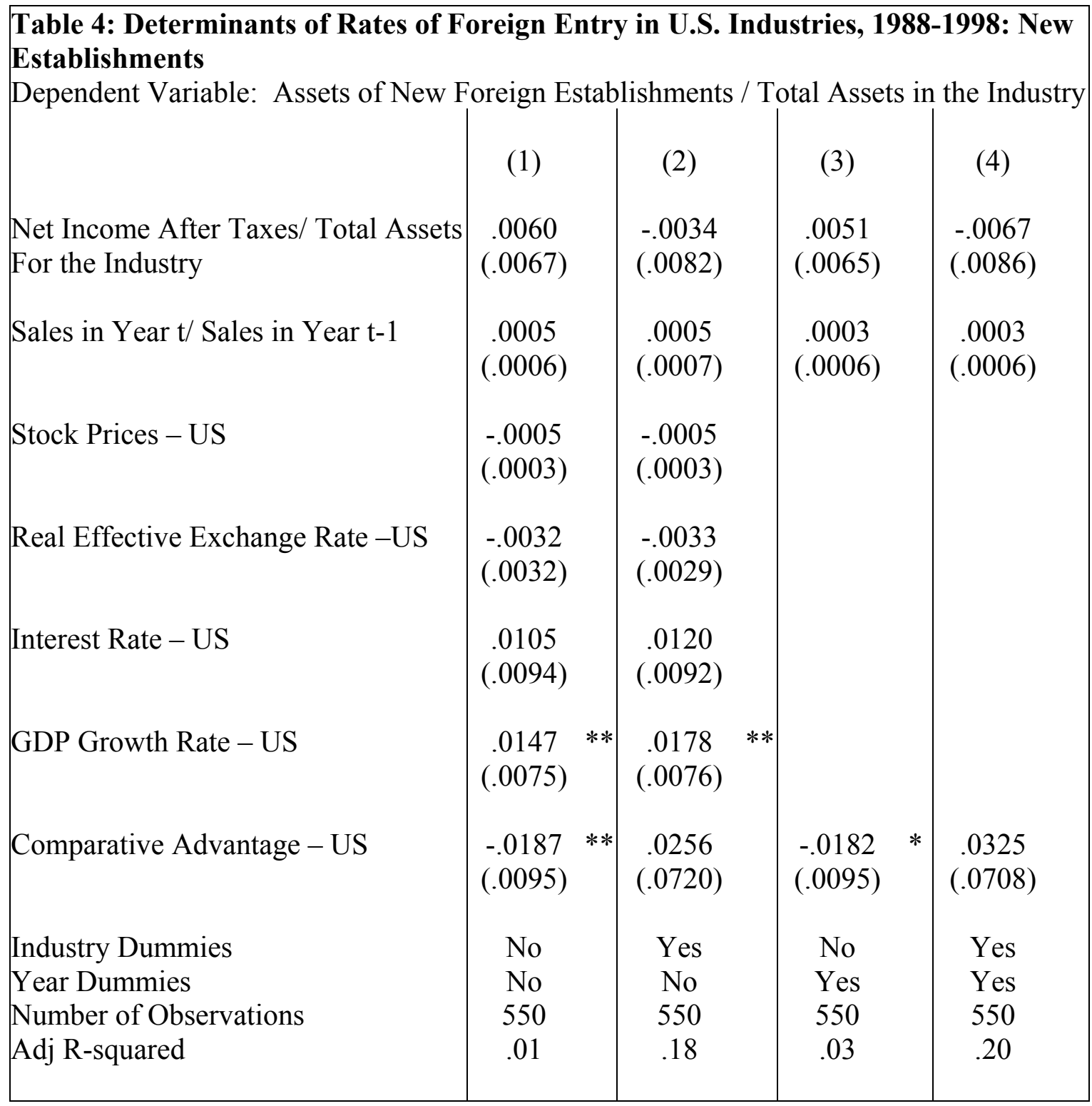

Numbers in Parentheses are Standard Errors.

* Significant at the $10 \%$ Level, ** Significant at the $5 \%$ Level 


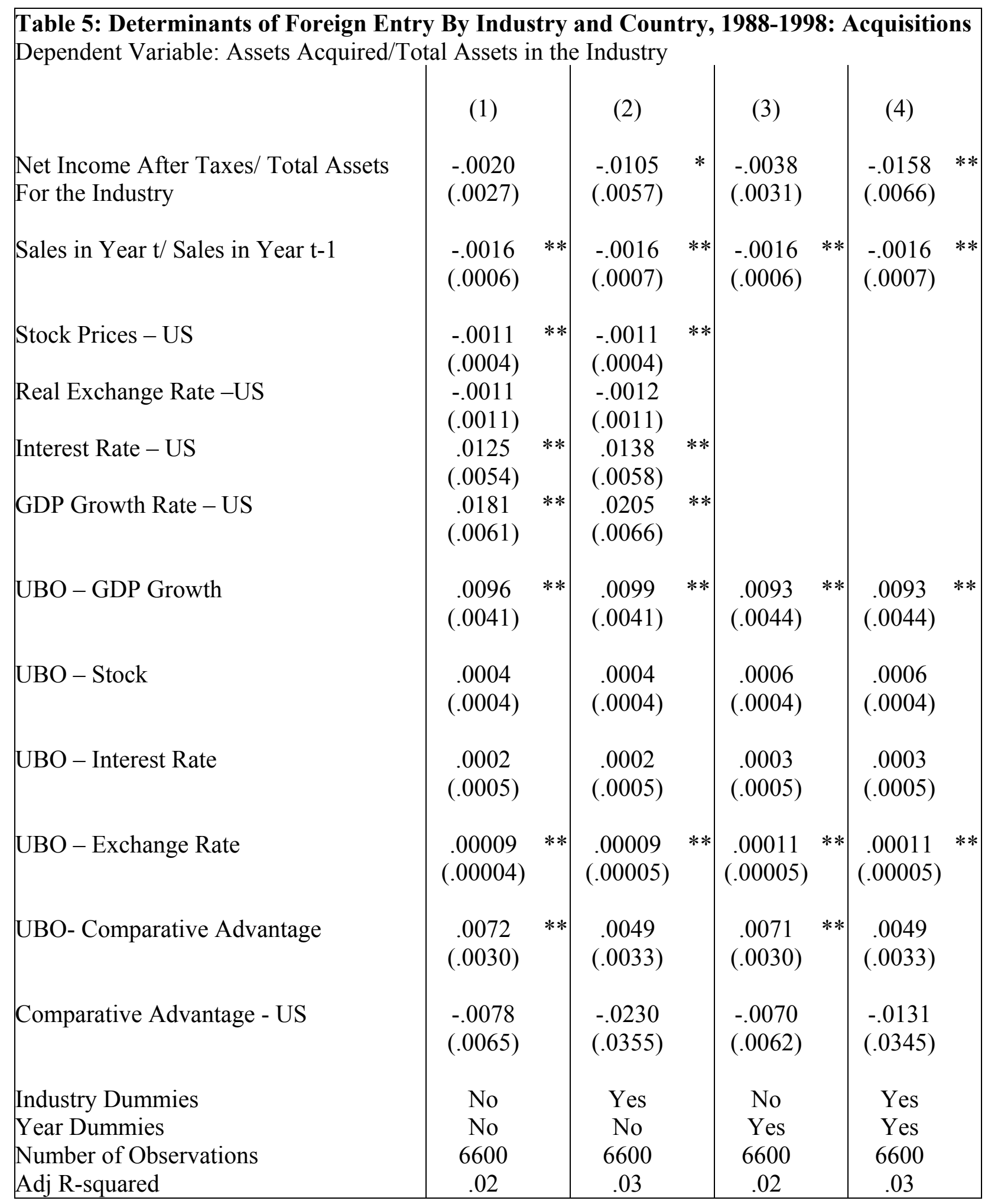

Numbers in Parentheses are Standard Errors.

* Significant at the $10 \%$ Level, ** Significant at the $5 \%$ Level 


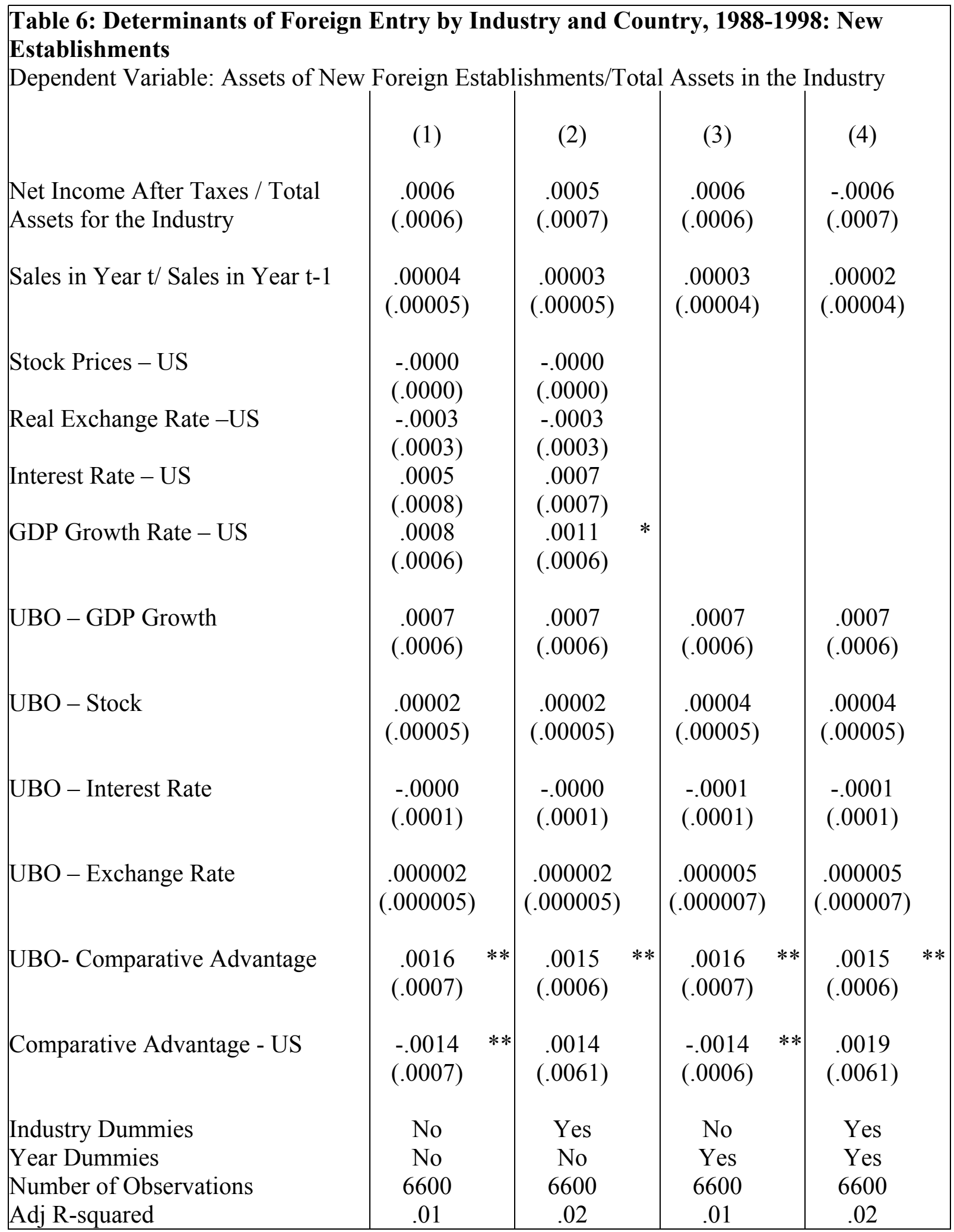

Numbers in Parentheses are Standard Errors.

* Significant at the $10 \%$ Level, ** Significant at the 5\% Level 